\title{
t......
}

\section{エッジ励起マイクロチップコンポジット Yb:YAGレーザー}

\author{
平等 拓範，常包 正樹，ダスカルトライアン \\ 分子科学研究所 分子制御レーザー開発研究センター（テ444-8585 愛知県岡崎市明大寺町字西郷中 38$)$
}

\section{Diode Edge-Pumped Microchip Composite Yb:YAG Laser}

\author{
Takunori TAIRA, Masaki TSUNEKANE, and Traian DASCALU \\ Institute for Molecular Science, Laser Research Center for Molecular Science, \\ 38, Nishigonaka, Myodaiji, Okazaki, Aichi 444-8585
}

(Received December 2, 2004)

\begin{abstract}
We present a simple concept for high-power microchip lasers by employing edge-pumped scheme for Yb:YAG core and YAG clad composite structure. Continuous-wave (CW) output power was up to $90 \mathrm{~W}$ from a $400-\mu \mathrm{m}-$ thick diffusion bonded Yb:YAG/YAG structure with a 10 at. $\%$ Yb:YAG square core of $2 \times 2 \mathrm{~mm}^{2}$; the slope efficiency and optical-to-optical efficiency with respect to the pump power were $40 \%$ and $28 \%$, respectively. Measurements of the optical phase distortions induced by pumping gives a focus shift bellow $0.05 \mathrm{~m}$ and shows the absence of astigmatic effects, indicating the axial heat flow in this pumping configuration. The newly developed microchip has circular, Yb:YAG single crystal core with $5 \mathrm{~mm}$-diameter, surrounded by transparent, undoped YAG ceramic pump wave-guide. Near $900 \mathrm{~W}$ pump light from fourfold stack with 6 diodes directly coupled to the edge windows of the ceramic wave-guide with $300 \mu \mathrm{m}$-thickness. Output powers of $380 \mathrm{~W}$ (peak) was reached in quasi-continuous-wave (QCW) $(10 \mathrm{~ms}, 10 \mathrm{~Hz})$ operation. Improved slope efficiencies and optical conversion were $50 \%$ and $44 \%$, respectively.
\end{abstract}

Key Words: Yb:YAG laser, Edge-pumping, Microchip laser, Au/Sn bonding, Ceramic YAG

1. はじめに

1980年代において進んだA1GaAs系半導体レーザー (Diode LaserまたはLaser Diode, 以下LDと省略)の高出力 化, 高効率化, 長寿命化に伴い進展した半導体レーザー 励起固体レーザー (Diode Pumped Solid-State Lasers, 以下 DPSSLと省略) は，それまでの固体レーザーの印象を一変 させた1． 放電管励起固体レーザーは，効率が悪く高圧大 電流を要し発熱も大きかったため, 強力な冷却装置が不 可欠とされた．また，頻繁に行わなければいけない放電 管の交換も面倒な作業の一つであったが, 何よりも出力 ビーム品質が低く, 多くの研究者達を悩ませてきた。現

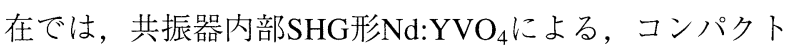
で実用的な $20 \mathrm{~W}$ 級の高ビーム品質緑色光源が市場に出回 るまでになっている。

LD励起は放電管励起に比べ発光スペクトルが狭いため に媒質の吸収波長に合わせることで高い吸収効率が得ら れ，コヒーレント光であるために集光性にも優れてい る，LDによって実現できる高密度励起により，レーザー 下準位が基底準位群に属する $\mathrm{Nd}^{3+}{ }^{4} \mathrm{~F}_{3 / 2}{ }^{-4} \mathrm{I}_{9 / 2}$ 遷移 $(946 \mathrm{~nm}$ ) の室温発振を可能にするなど質的な転換をも引き起こし
た2).このような中で, T. Y.Fanが, Yb:YAGの ${ }^{2} \mathrm{~F}_{5 / 2}{ }^{-2} \mathrm{~F}_{7 / 2}$ 遷移 $(1.03 \mu \mathrm{m})$ は厳密には三準位レーザーではなく, 強励 起下では下準位吸収が飽和する，いわゆる準四準位レー ザーであることを示した ${ }^{3)}$. 当初問題は励起用のLDが入 手困難なことにあったが, 折からの光通信市場の活性化 でEDFA用900 nm帯InGaAs系LDの普及, 高性能化が急速 に進み，今やYb:YAGは代表的な固体レーザーである $\mathrm{Nd}$ : YAGを凌ぐポテンシャルを有する高出力, 高効率レー ザーとしての認識が定着したとまで言え る4-6).

本稿では，筆者等が進めてきたYb:YAGマイクロチップ レーザーの一連の研究を概説するとともに, エッジ励起 $\mathrm{Yb}: \mathrm{YAG}$ マイクロチップレーザーの高出力化の開発状況を 紹介したい.

\section{2. $\mathrm{Yb}: Y A G の$ 基本特性}

\section{1 分光特性}

三価のイッテリビウムイオン, $\mathrm{Yb}^{3+}$, は, $[\mathrm{Xe}]^{4} \mathrm{f}_{11}{ }^{6} \mathrm{~s}_{2}$ 電子 構造であるため ${ }^{2} \mathrm{~F}_{5 / 2}$ と ${ }^{2} \mathrm{~F}_{7 / 2}$ の二準位しか存在せず, 励起状 態吸収 $(\mathrm{ESA})$ などのアップコンバージョン損失などが起こ 
らない事より，高密度励起に適していると言える。何よ りもYb:YAGレーザーは，Fig. 1 (a)に示すように励起波長 が940 nm, レーザー発振波長が1030 nmなので励起量子効 率は91.4\%にも達する。このためNd:YAGでは励起に付随 する発熱率が43\%であるのに対しYb:YAGでは10\%前後に 抑えられるため3４倍の高出力化が期待できる7). また， $\mathrm{Yb}^{3+}$ のイオン半径が $\mathrm{Y}^{3+}$ のれに近いため高添加時の濃度 消光が起き難く $100 \%$ 置換されたYbAGにおいてもレー ザー発振が確認されている8). 上準位寿命は約 $1 \mathrm{~ms}$ と $\mathrm{Nd}$ : YAGの4倍程度長く，高いエネルギー蓄積効果も期待され るなど優れた特長を有する ${ }^{9)}$.

$\mathrm{Yb}^{3+}$ 添加濃度25at. \%のYAGにおける850 1100 nm付近 の吸収スペクトル特性の測定結果をFig. 1 (b) 示す10). $\mathrm{Yb}$ : YAGの吸収スペクトル半值幅は約 $18 \mathrm{~nm}$ と Nd:YAGの吸収

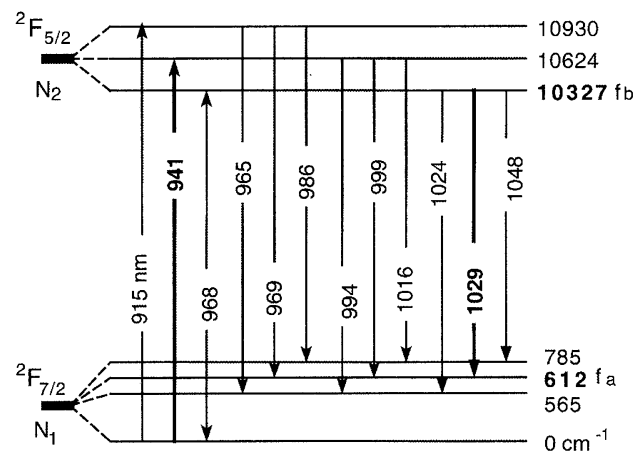

(a)

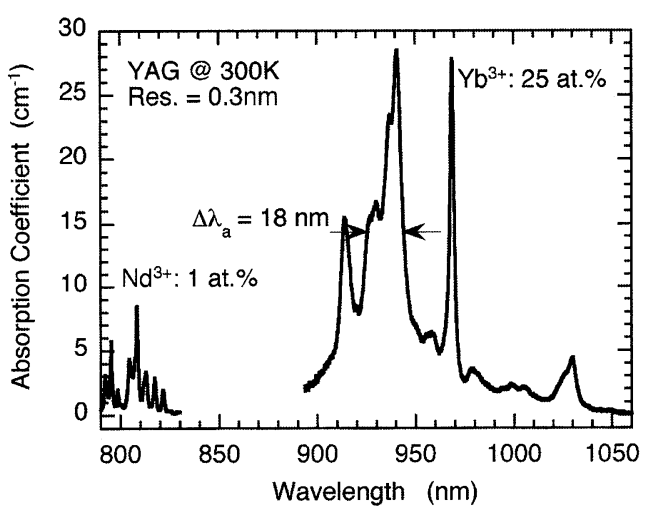

(b)

Fig. 1 Energy level diagram (a) and measured absorption spectrum (b) of Yb:YAG.
スペクトルに比べ15倍近く広く，LDの発振波長に対する 制限が緩和される。また，もう一つの吸収線である 970 nmを用いれば，さらに高い94\%以上の量子効率も期待で き，より高効率動作が可能となる. 今後, 高出力動作が 可能な動作波長 $970 \mathrm{~nm}$ の励起用LDの実用化が待たれる. 加えて, $900 \mathrm{~nm}$ 帯の励起にはAlGaAsよりも信頼性の高い とされるInGaAs系のLDによる励起が可能である。すでに 寿命の点で優位であることが報告されつつあり11), 今後 の価格の面でも優位性が高くなるものと期待される.

また, Table 1に, Yb:YAGおよびNd:YAGの材料特性比 較を示す6,9,10). Yb:YAGは熱発生が少ないことに加え，蛍

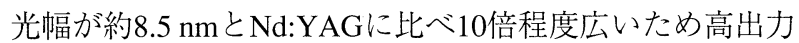
の波長可変動作や超短パルス発生などが期待できる。な お，分光的に求めた蛍光寿命は $0.85 \mathrm{~ms}$ であた。 Fig. 2 に 分光的に求められた誘導吸収及び誘導放出断面積の特性

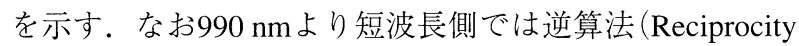

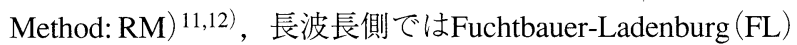

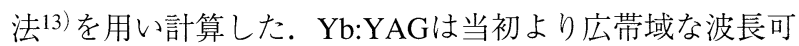
変動作が可能であると期待され，検討が行われた。 Fig. 3 はYb:YAGマイクロチップレーザーの共振器内に複屈折 フィルターを挿入し, 波長可変特性を測定した結果であ

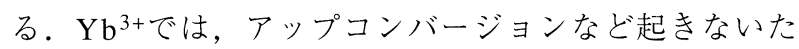
め, $1024.1 \mathrm{~nm}$ から $1108.6 \mathrm{~nm}$ と, 蛍光幅の10倍に相当する $84.5 \mathrm{~nm}$ の可変幅を得ている14).これらの優れた特性を有 するYb:YAGにおいて，その高出力化のみならず，広い蛍 光幅を利用した超短パルス発生に関する検討も盛んに進 められている15).

なお，準四準位レーザー媒質の吸収量の評価について は注意が必要であり，付録Aを参照されたい。

\section{2 レーザー材料形状}

高出力化の観点からレーザー母材に求められる特性と しては，1）熱伝導率および抗張力が高いこと，2）高品質 で大型の材料育成が可能なこと，3）励起波長や発振波長 域で吸収損失が少ないこと等が挙げられる，特に，熱機 械特性としては，レーザー最大出力を制限するため各種 材料の熱衝撃パラメータ $R_{\mathrm{T}}$ が評価されている16). 代表的 な構成をFig. 4に示す。同図 (a)のロッド状レーザー媒質を 側面励起した場合，励起に付随した発熱によりロッド中 心では圧縮力が，表面では張力が㗢き，最終的に応力破 壊に至るため出力の抽出限界 $P_{\mathrm{ex}}$ は

Table 1 Optical properties of Yb:YAG and Nd:YAG

\begin{tabular}{lcc}
\hline \hline \multicolumn{1}{c}{ Parameter } & Nd:YAG & Yb:YAG \\
\hline Pump wavelength $\lambda_{\mathrm{p}}(\mathrm{nm})$ & 808.4 & 940.6 \\
Absorption bandwidth $\Delta \lambda_{\mathrm{p}}(\mathrm{nm})$ & 1.2 & 18 \\
Absorption cross-section $\sigma_{\mathrm{a}}\left(\lambda_{\mathrm{p}}\right)\left(\times 10^{-20} \mathrm{~cm}^{2}\right)$ & 6.59 & 0.82 \\
Peak emission wavelength $\lambda_{\mathrm{e}}(\mathrm{nm})$ & 1064.2 & 1030.1 \\
Emission bandwidth $\Delta \lambda_{\mathrm{e}}(\mathrm{nm})$ & 0.67 & 8.5 \\
Emission cross-section $\sigma_{\mathrm{e}}\left(\lambda_{\mathrm{L}}\right)\left(\times 10^{-20} \mathrm{~cm}^{2}\right)$ & 26.3 & 2.1 \\
Absorption cross-section $\sigma_{\mathrm{a}}\left(\lambda_{\mathrm{L}}\right)\left(\times 10^{-21} \mathrm{~cm}^{2}\right)$ & 0 & 1.3 \\
Min. pump intensity $I_{\min }\left(\mathrm{kW} / \mathrm{cm}^{2}\right)$ & 0 & 1.87 \\
Intrinsic lifetime $\tau_{0}(\mathrm{~ms})$ & 0.28 & 0.85 \\
Quantum defect fraction & 0.24 & 0.11 \\
\hline
\end{tabular}




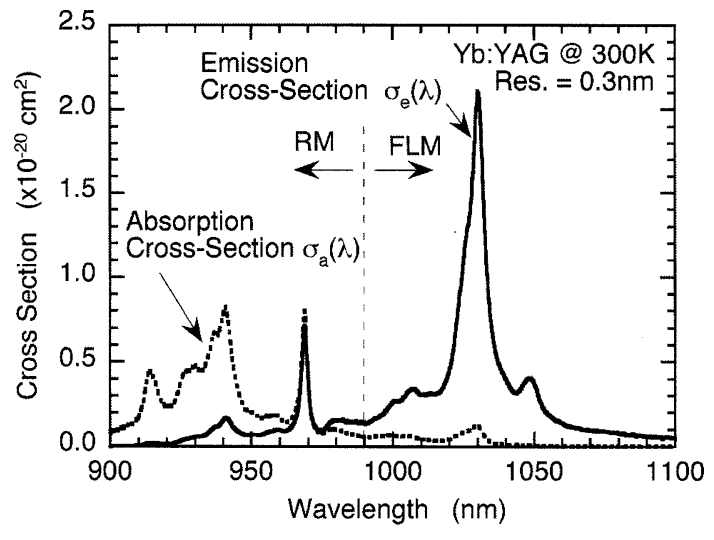

Fig. 2 Absorption and emission cross-sections of Yb:YAG measured by Reciprocity Method (RM) and Fuchtbauer-Ladenburg Method (FLM).

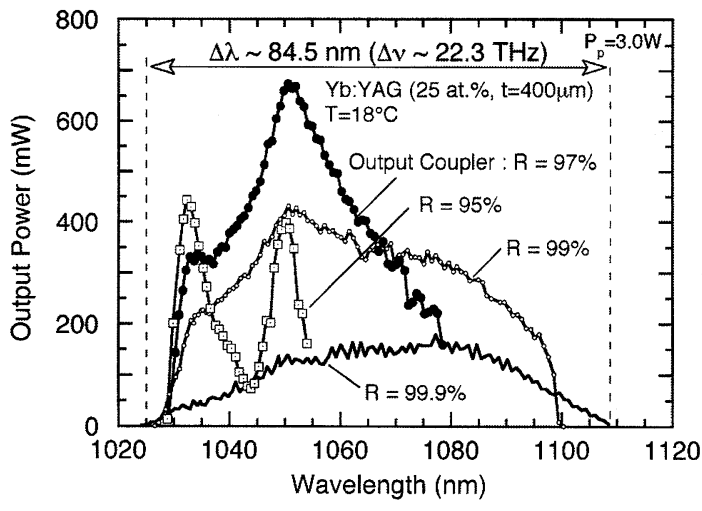

Fig. 3 Tuning characteristics of the Yb:YAG microchip laser for different output coupler reflectivities.

$$
P_{\text {ex }} \leq \frac{8 \pi R_{\mathrm{T}} L}{\chi}
$$

で与えられる22)。ここで，Lはロッド長， $\chi$ は発熱率で反 転分布量に対する発熱量比として定義される17)。(1)式よ りも, ロッド状のレーザ媒質では, 最大到達可能出力は 熱衝撃パラメータ $R_{\mathrm{T}}$ に比例することがわかる.さらに, Fig. 4 (b)の面冷却の薄型ディスク ${ }^{18,19)}$ またはマイクロチッ プ状のアクティブミラーレーザー20)の場合も同様の表式 で表す事ができる23).

$$
P_{\text {ex }} \leq \frac{12 R_{\mathrm{T}}}{\chi}\left(\frac{A}{t}\right)
$$

ここで，Aは励起(冷却)面積, $t$ はその厚みである。また, 同図 (c)のスラブレーザー21,22) も面冷却であるため，スラ ブ幅を $w$ とするなら冷却面積が $A=w L$ あるることからも括 弧の中の因子が $L(w / t)$ に置き換わるだけである. 本質的に は，アクティブミラーレーザーの抽出限界はスラブレー ザーと同様の表式に帰着する。 なお，スラブの抽出限界 特性には, ロッドに比べ $(w / t)$ の因子が付加されるため容 易に大きな抽出限界を得る事ができる23). しかも，これ 以前に, ロッド構成では熱複屈折や熱レンズ効果により レーザー出力が低下，不安定化するため何らかの補償が 必要となる。スラブレーザーやアクティブミラーの場

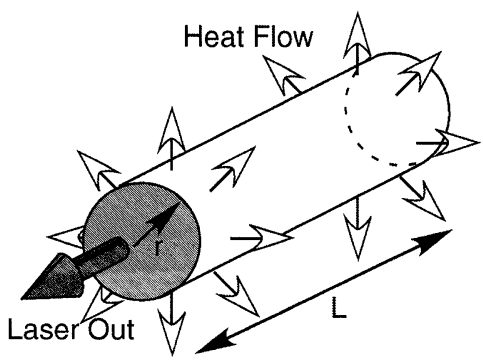

(a)

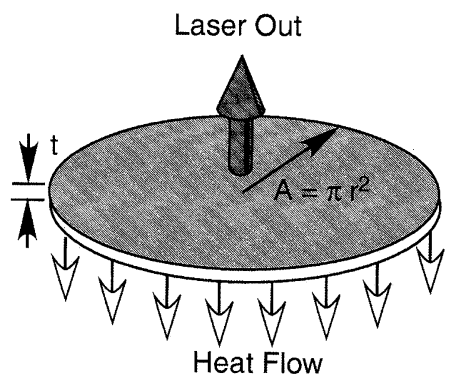

(b)

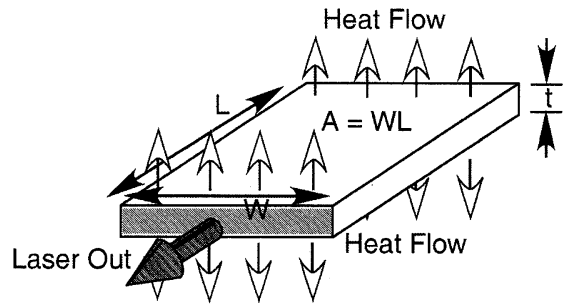

(c)

Fig. 4 Heat flow and beam propagation for typical solidstate laser configurations of rod (a), disc (b) and slab (c).

合，このような問題は原理的に発生しない. しかも，固 体レーザーの特長の一つであるパルス化, 特にサブピコ 秒の超短パルス化に関して，2つの点でアクティブミラー 構成は優位と言える。まず，パルス発振の場合，時間的 にエネルギーの尖頭值が高くなるが，アクティブミラー 構成の場合レーザー媒質内でのビーム断面積を大きくと ることでエネルギー密度を抑えることができ，レーザー 媒質のダメージに対して有利である. 次に, 超短パルス 発生の場合, 自己位相変調に群速度分散遅延が発生する が, この值は媒質長に比例するため, 厚みの薄いマイク ロチップ形状のアクティブミラー構成が有利となる.

次節では, 超短パルス発生を見据えた研究の一端とし て, マイクロチップ構成の高出力化について検討する.

\section{3. 高出カYb:YAGレーザー}

\section{1 エッジ励起構成}

Fig. 5に，エッジ励起形マイクロチップレーザーの基本 構成を示す24,25). 励起光はチップ側面から無添加YAGの 導波部を経て, レーザー活性部，ここでは $\mathrm{Yb}^{3+}: \mathrm{YAG}$ の領 域に導かれる。また，チップ端面が直接ヒートシンクに 


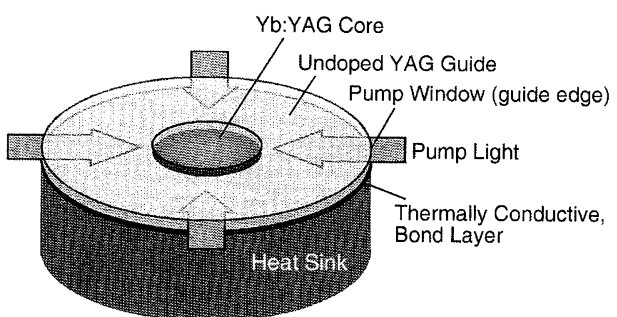

(a)

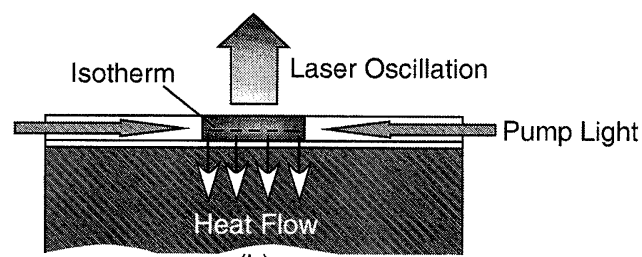

(b)

Fig. 5 Configuration of diode edge-pumped, composite microchip Yb:YAG laser, top (a) and cross-sectional view (b).

接合することにより，効率の良い冷却が可能なだけでな く，温度分布がビーム断面に平行になるため原理的には 熱レンズ，熱複屈折が生じないことが期待できる。な お，このエッジ励起マイクロチップレーザーは，励起方 法は異なるものの面冷却での排熱やレーザー発振器の構 成はいわゆる「薄型ディスクレーザー」18,19) とほぼ同じであ る.しかしながら著者(平等)は90年より端面励起，側面冷 却構成のマイクロチップレーザーの研究に着手してお り, 今回説明するエッジ励起, 面冷却構成もその研究の 延長上の一つの発展型と捉えている。従って本文中にお いてもレーザー媒質に対しマイクロチップと言う名称を 統一的に用いている。また一方「アクティブミラー」という 表現は，本文中では媒質内にレーザー光を反射する面を 有する面冷却の利得媒質あるいはそれを含んだレーザー の概念，総称として用いている.

さて，温度分布計算を市販の有限要素解析プログラム であるアンシス (Ansys Inc., ANSYS ED 7.0)を用いて計算 した結果をFig. 6に示す26).この時，直径5 mmのYb:YAG (5 at.\%) コアを全体直径8 $\mathrm{mm}$ となるようYAGクラッドで 取り巻き，チップ下面を全反射コーティング $(\mathrm{HR})$ 層，接 合層を経て銅製のヒートシンクに接合する構成とした。 なお，コア部からの熱発生は約 $1 \mathrm{~kW}$ の励起入力時を想定 して $100 \mathrm{~W}$ と仮定し，ヒートシンクの厚みは $1.5 \mathrm{~mm}$ ，冷却 水と接するヒートシンク下面のマイクロチャンネル表面 における熱伝達係数は実験的に求められた值 $\left(60 \mathrm{~kW} / \mathrm{m}^{2} \mathrm{~K}\right)$ を用いた，HR層は厚み $4 \mu \mathrm{m} て ゙$ 熱伝導率 $1.4 \mathrm{~W} / \mathrm{mK}$ ，接合に は実験的に高熱伝導接着剤と $\mathrm{Au} / \mathrm{Sn}$ 混晶の両方を検討して いるが，より温度上昇の厳しい接着剤の条件である厚み4 $\mu \mathrm{m}$ ，熱伝導率6 W/mKを想定した. Fig. 6 (a) はチップの 厚み $400 \mu \mathrm{m}$ におけるヒートシンクを含む2次元の断面温度 分布であり高温部を黒く濃く，低温部を白く示してい る。コアの中央部近傍ではチップの面にほぼ平行に温度 分布が形成されることが分かる。同図 (b) は，そのコア中 心での厚み方向の温度分布を示したもので，パラメータ
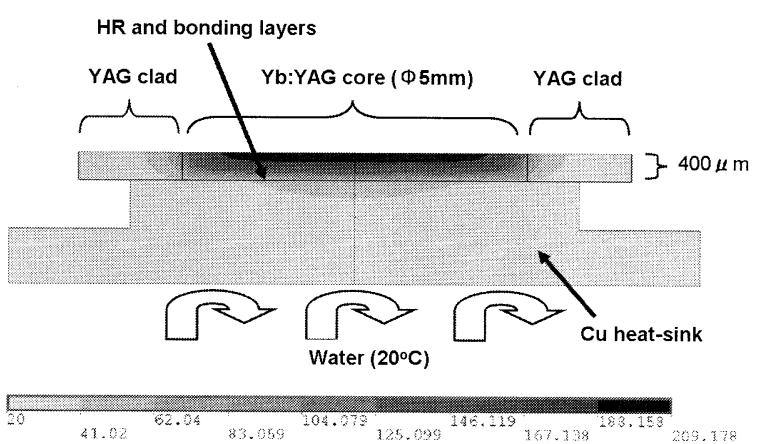

(a)

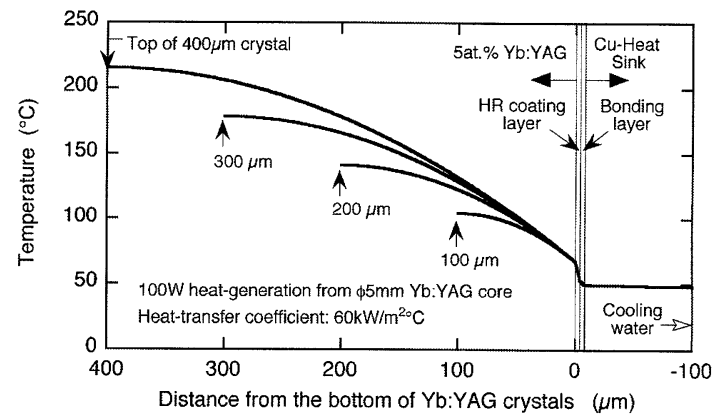

(b)

Fig. 6 Calculated temperature profile of composite Yb:YAG microchip bonded on copper heat-sink, cross-sectional 2D contour map with 0.4-mm-thickness microchip (a) and 1D profiles at the center as a function of microchip thichkness (b).

としてチップの厚みを $400 \mu \mathrm{m}$ から $100 \mu \mathrm{m}$ まで変えて計算 したものである。コア内での総発熱量は100 Wで同じとし た。当初，接着層近傍での温度上昇が懸念されたが，む しろYAG媒質部内部での温度上昇の方が大きく，同じ総 発熱量でも媒質厚が薄くなることによるコア内での温度 低減効果が非常に大きいことが分かった。エッジ励起方 式においてはチップの厚みが薄くなってもコアにおける 高い吸収率が維持できるために，チップの薄膜化はレー ザー媒質内の温度低減によるレーザー出力の向上，効率 の改善に非常に有利である。

3.2 エッジ励起マイクロチップレーザー発振特性

3.2.1 単結晶Yb:YAG/YAGコンポジット

Fig.7に，4万向エッジ励起用マイクロチップコンポジッ トYb:YAGをヒートシンクにマウントしたへッド外観を示 す27,28). レーザー媒質として，2 $\mathrm{mm} \times 2 \mathrm{~mm} の 10$ at.\% Yb: YAG単結晶コア部を，無添加単結晶YAGが取り囲むよう に拡散接合 (ONYX Optics Inc.) し，外径9 mmのロッド形 成したものから，厚み $400 \mu \mathrm{m}$ に薄く研磨加工すること で，複数枚のYb:YAG/YAGコンポジット構造マイクロ チップを作製した。さらに，ヒートシンクとの接合面側 にレーザー発振波長である $1030 \mathrm{~nm}$ に対し全反射，反対面 に無反射コーティングを施した．Fig. 7では，このチップ を200 $\mu \mathrm{m}$ チャンネル幅の横水流型マイクロチャネルヒー トシンクに $\mathrm{Au} / \mathrm{Sn}$ 混晶化反応により接合している。なお， 


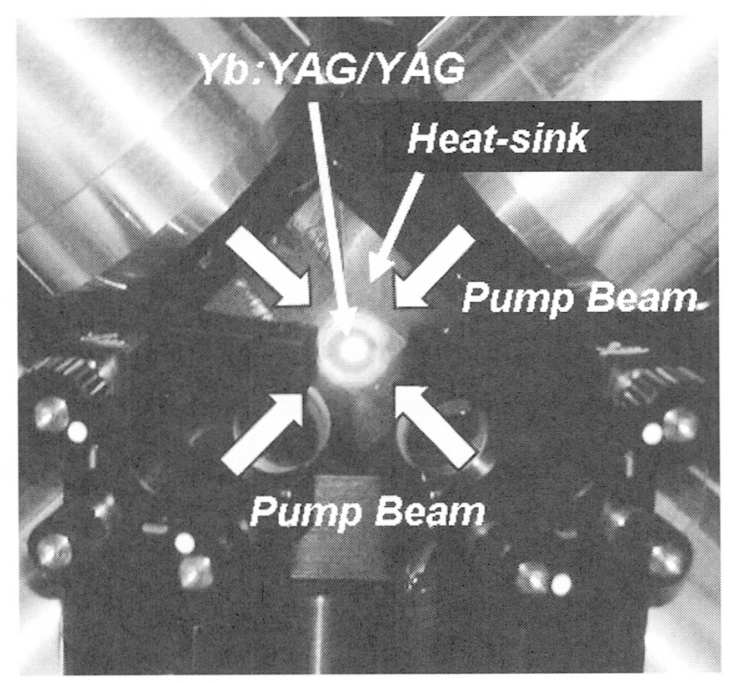

Fig. 7 Composite single-crystal Yb:YAG core (2-mmsquare)/single-crystal YAG clad microchip bonded on a microchannel hea-sink with transverse waterflow for four-fold edge-pumped laser system.

励起光取り込み用に幅 $2 \mathrm{~mm}$ の空をチップ側面形成する際 に，寄生発振を防ぐため斜め研摩 $\left(3 \sim 5^{\circ}\right)$ を施している。 励起には, 中心波長 $940 \mathrm{~nm}$ のファイバー結合形LD (JOLD100-CAXF-15A, JENOPTIK Laserdiode) 光をレンズにて励起 空に集光し, 用いた。この時, 測定された励起光吸収効 率は約74\%と高く, 式 $(2)$ の $(A / t)$ を大きくしなければいけ ないという要請は, エッジ励起の場合, 厚みに関係なく 吸収光路を長くとれるため, 簡単な励起光学系でも吸収 効率を高くできることになり高出力化に有利であること が分かる.

このエッジ励起マイクロチップYb:YAG/YAGレーザー の入出力特性をFig. 8 に示す。共振器は, 曲率 $100 \mathrm{~mm}$ の出 力結合鏡を, チップから約 $50 \mathrm{~mm}$ 位置に配置し, 半共焦点 形構成とした。透過率 $T=5 \%$ 時に出力最大となり, 90.2 $\mathrm{W}$ 得られた。この時の励起入力は $318 \mathrm{~W}$, しきい值は約 $55 \mathrm{~W}$ で，その倍程度の励起に対するスロープ効率は40\% であった。 $T=3 \%$ 場合, しきい值は約 $40 \mathrm{~W}$ と改善でき るが, スロープ効率は37\%と低下した。 T= $10 \%$ ではさ らに31\%スロープまで低下した，ところで，Yb:YAGコア

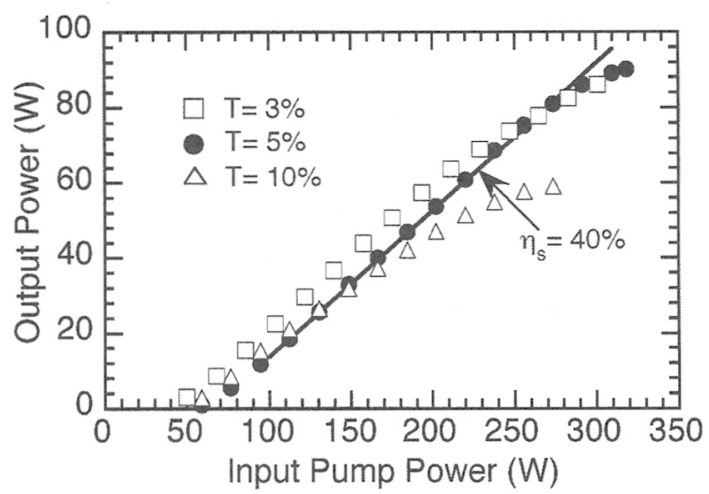

Fig. $8 \mathrm{CW}$ output power versus input pump power for the fiber-coupled diode edge-pumped composite Yb:YAG/YAG laser.
面積は, 上記の共振器構成の基本モードの面積に比べ数 10 倍大きいため, その発振モードは高次横モードとな る。そこで, 平面全反射後部鏡と曲率 $1 \mathrm{~m}$ の出力鏡によ り, 長さ $660 \mathrm{~mm}$ のV形共振器を構成し, 後部鏡から約 360 mm位置にYb:YAGチップを配置することにより横モード の低次元化を図った。最大出力は約 $25 \%$ 低下したもの の，M值は5程度まで改善された。

次に, Fig. 9に示す構成にて励起に付随した発熱による 波面歪みについて評価を行った。直径 $3 \mathrm{~mm}$ の $\mathrm{He}-\mathrm{Ne}$ の出力 光をプローブとし Yb:YAG結晶を 1 往復させ，その透過光 をシャックハルトマン波面センサー(Wavefront Science Inc., CLAS 2D)にて解析を行った。測定の結果，拡散接合 周辺は大きな歪みが残っており，これがレーザー発振横 モードを劣化させている1つの原因と分かった。さらに， 評価を進めるため, コア中心部の直径 $1.9 \mathrm{~mm}$ 領域のみ選 択し, Zernike係数を抽出した。これにより出力波面が再 構築される。得られた係数 $C_{2,1}$ より曲率 $R_{\mathrm{c}}=R_{\mathrm{z}}^{2} /\left(2 C_{2,1}\right)$ が 求まり, これより等価的焦点距離 $f=R_{\mathrm{c}} /(n-1)$ が計算され る。また，係数 $C_{2,0}$ と $C_{2,2}$ は歪みを表す量である。ここ で， $R_{\mathrm{Z}}$ はZernike円形マスクの大きさを表す因子で，nは レーザー媒質の屈折率である。なお，これらを除く高次 係数は小さいため無視した。解析より得られた焦点シフ 卜と歪み変化をFig. 10に示す28). 入射励起パワー40 Wか ら $180 \mathrm{~W}$ 範囲内で，焦点シフト量はほぼ一定で $0.05 \mathrm{~m}$, 歪みの変化も $0.01 \mathrm{~m}$ と良好な結果を得た。このことは, $\mathrm{Au} / \mathrm{Sn}$ 混晶により結晶と金属間で高い面内均一性を維持し たまま，低い熱抵抗接合が可能であることを示すもので ある。

\subsection{2 単結晶Yb:YAG/セラミックYAGコンポジット}

近年国産での透光性セラミックを媒質とした様々な固 体レーザーの研究が注目されている。また同時にセラ ミックの自由度の高い製法を利用して製作したコンポ ジット構造は, 前節で述べた結晶同士のコンポジット構 造に比べ, 量産性やコスト, 納期の点から将来の産業用 の固体レーザー媒質として実用性が高いと考えられる。

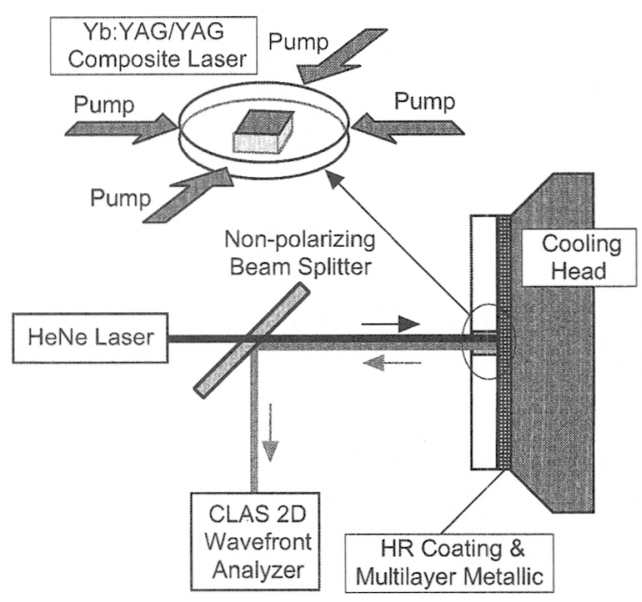

Fig. 9 Experimental setup for thermal effects measurements in the microchip composite Yb:YAG/YAG laser. 
そこでさらにマイクロチップとしてセラミックによるコ ンポジット構造を検討した. Fig. 11にその構成を示す。 レーザー媒質には，5 at.\% Yb:YAG単結晶を直径 $5 \mathrm{~mm} に 丸$ め, その周辺に無添加のセラミックYAGクラッドを焼結 し, 直径 $10 \mathrm{~mm}$ の単結晶 $\mathrm{Yb}: \mathrm{YAG} /$ セラミックYAG複合構造 を形成させた(神島化学工業：Konoshima chemical co. Ltd). これを $300 \mu \mathrm{m}$ 厚に切り出し研摩し, 側面に4ヶ所, $6 \mathrm{~mm}$ 幅の空を研磨作製した。チップの両面には先と同様 のコーティングを施し, HR面を高熱伝導率接着片を用い てヒートシンクに接合させた。励起にはコリメートレン ズ付き6バースタックLD(JOLD-240-CAFN-6A, Jena Optics) を組み合わせレンズを用いて $0.1 \mathrm{~mm} \times 4 \mathrm{~mm}$ に集光しマイ クロチップエッジ端面に導入した。 Fig. 12にヒートシンク に接合した単結晶Yb:YAG/セラミックYAGコンポジット 構造マイクロチップレーザーの外観を示す.

ヒートシンクには, 従来の横水流型のマイクロチャン ネル構造からチップを接合する面の裏側にマイクロチャ ンネル構造を設け，チャンネルに対して縦水流で直接冷 却媒体を衝突させる構造とした。ヒートシンクに70Wの LD光を照射し, その泠却特性を評価したところ, 従来の 構成では約 $80{ }^{\circ} \mathrm{C}$ ま゙昇した表面温度が， $35^{\circ} \mathrm{C}$ 程度まで

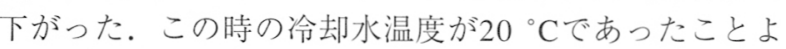
り，冷却能力にして約4倍向上したことになる26)。この ヒートシンクの採用によりレーザー特性の大幅な向上が 期待される.

Fig. 13にレーザー発振入出力特性を示す。まず，透過率 $97 \%$, 曲率 $25 \mathrm{~cm}$ の出力結合鏡を共振器長 $50 \mathrm{~mm}$ で配置す ることにより，CW動作にて最大出力 $120 \mathrm{~W}$ 励起 $399 \mathrm{~W}$ 時に得た。入射光に対するスロープ効率は39\%，全体効 率30\%であった。次に，準CW $(\mathrm{QCW})$ 動作にてその特性 を評価した。繰り返し $10 \mathrm{~Hz}$ ，デューティ10\%動作時に， 最大出力 $380 \mathrm{~W}$, スロープ効率は50\%, 全体効率44\%を 室温で得ることに成功した29)。これらの結果は，エッジ 励起Yb:YAGマイクロチップレーザー構成においては, 複 雑な励起構成を用いなくとも高効率なアクティブミラー レーザーが実現できることを示すものである，なお，現 在, マイクロチップとヒートシンクの接合に, 先に試し た $\mathrm{Au} / \mathrm{Sn}$ 混晶接合法を適用することでさらなる高平均出力

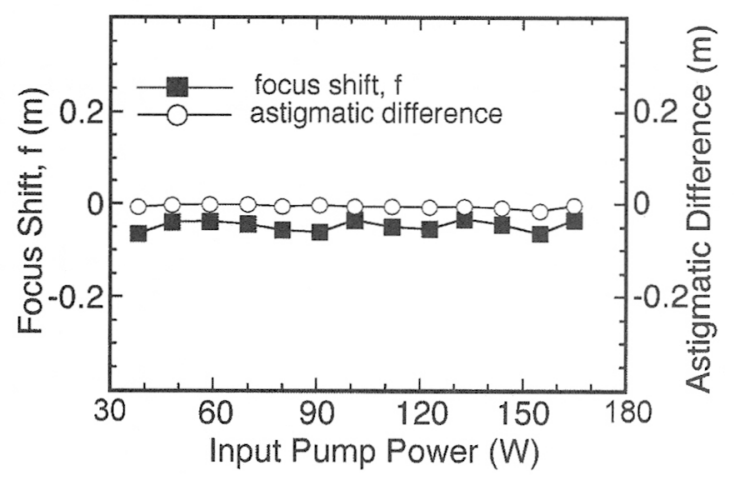

Fig. 10 Focus shift and astigmatic difference between sagittal and tangental plane vs pimp power for a HeNe probe beam that pass forth and back the Yb:YAG core.

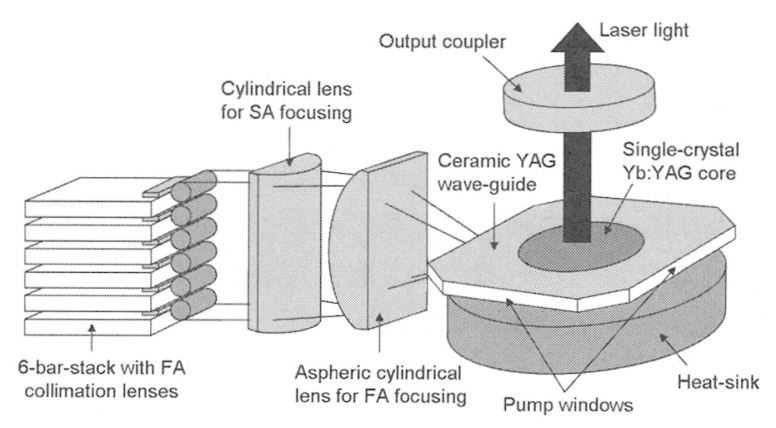

Fig. 11 Schematic of directly-coupled diode edge-pump composite microchip Yb:YAG/YAG laser.

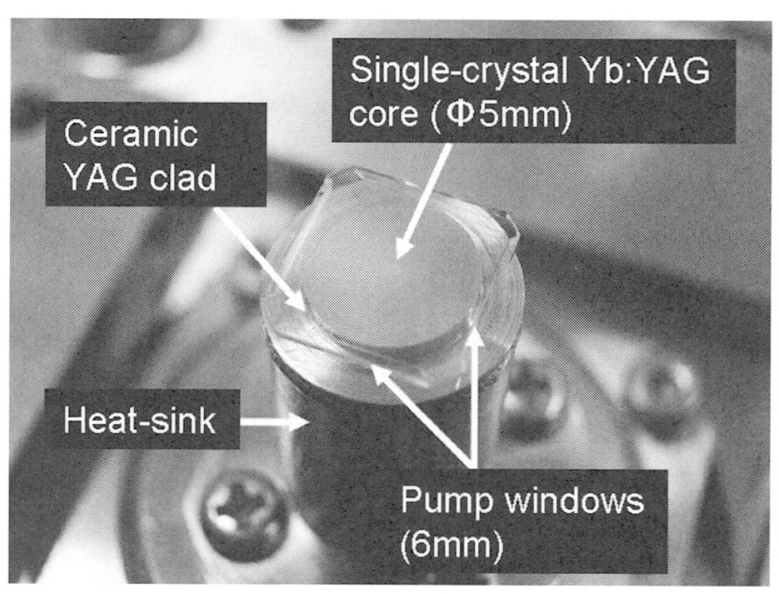

Fig. 12 Composite single-crystal Yb:YAG core/ceramic YAG clad microchip bonded on a microchannel heat-sink with vertical water-flow, impingement jet cooling.

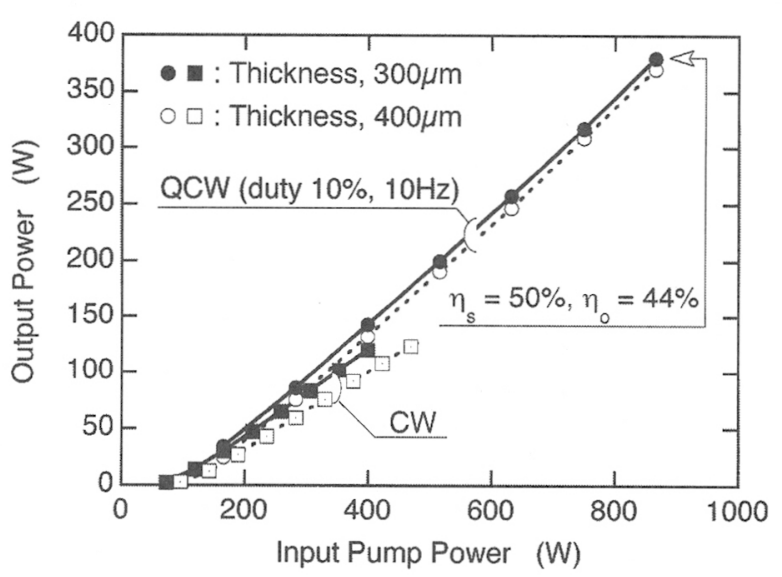

Fig. $13 \mathrm{CW}$ and QCW output power versus input pump power for the new composite Yb:YAG/YAG laser.

動作の実証を検討中である.

\section{4. まとめ}

以上，エッジ励起マイクロチップレーザーについて検 討を行ってきた。アクティブミラーの特長を備えたこの レーザーは, 結晶厚を薄くし, その面積を広げることで 平均出力数 $\mathrm{kW}$ 超える高出力動作も可能と期待される. 問題は，如何に簡単な構成で薄くなるレーザー媒質にお 
ける励起光吸収効率を高めるかであり, また，如何に理 想的なヒートシンクへの接合を実現するかであった。ま ず，拡散接合法を用いレーザー活性領域と導波部を接合 したコンポジット構成において，エッジ励起方式を検証 し，簡単で高効率励起が可能であることを検証した。さ らに，焼結法を用いることで簡便に求められる複合構造 を作製できることを示した。

次の問題であった，低い熱抵抗でレーザー媒質と冷却 媒体とを接合する手法に関して，高熱伝導率の接着剂と $\mathrm{Au} / \mathrm{Sn}$ 混晶化反応を利用した異種材料接合について検討し た。最初に拡散接合による単結晶Yb:YAG/YAGマイクロ チップを $\mathrm{Au} / \mathrm{Sn}$ 混晶によりマイクロチャンネルヒートシン クに接合し，室温にて最大CW出力 $90.2 \mathrm{~W}$ をスープ効率

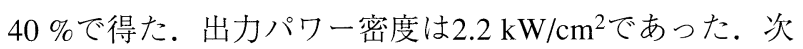
に，焼結法により作製した単結晶Yb:YAG/セラミック YAGを接着剤を用いヒートシンクに接合し，QCWにて $380 \mathrm{~W}$ オロープ効率50\%で得た. CWでも $120 \mathrm{~W} 39 \%$ 効率で得ており，接着剤による接合でもかなりのポテン シャルを有している事が分かった．高熱伝導性接着剤に よる接合は製作プロセスの簡素化やコストの点でも有利 であり，低出力レーザーへの適用も十分考えられるため 引き続き注目して行きたい.またさらなる高出力化を実 現するために, $\mathrm{Au} / \mathrm{Sn}$ 混晶による接合技術の最適化も進め ており，ごく最近CWで300W超の動作も確認している.

ところで，Yb系レーザーでは，その広い利得幅を利用 した超短パルス発生が試みられている. 我々もYAGにSc を導入したYb:YSAGセラミックスを用いて280 fsまでの超 短パルスを得ており ${ }^{30)}$ ，さらに短パルス化が可能である 事が分かっている．今後の展開として，超短パルスを用 いた非熱効果による機能性材料加工に対する検討のた め，エッジ励起マイクロチップレーザーを用いて高平均 出力超短パルス発生に関する検討を進める予定である.

\section{謝 辞}

本研究は文部科学省による福井県地域結集形共同研究 事業 (CREATE)「光ビームによる機能性材料加工創成技術 開発」の一環として分子科学研究所にて行われた。 また本 研究の遂行に当りご協力, ご助言頂いた当研究室の斎川 次郎君, 佐藤 庸一博士, またヒートシンクやレーザー ヘッドの製作に関し分子科学研究所, 装置開発部の鈴井 班長に感謝する. またさらに励起光の集光, 接着剤を用 いた結晶のヒートシンクへの接合に関し, ご協力頂いた 三菱電機情報総合研究所の平野 嘉仁博士, 山本修平氏に 感謝する。

\section{参考文献}

1) R. L. Byer: Science 239 (1988) 742.

2) T. Y. Fan and R. L. Byer: IEEE J. Quantum Elecron. QE-23 (1987) 605.

3) P. Lacovara, H. K. Choi, C. A. Wang, R. L. Aggarwal, and T. Y. Fan: Opt. Lett. 16 (1991) 1089.

4) 平等 拓範：光技術コンタクト 35 (1997) 682 .

5) 平等 拓範：光学 28 (1999) 435.
6) W. F. Krupke: IEEE Journal of Selected Topics in Quantum Electrons 6 (2000) 1287.

7) D. C. Brown: IEEE J. Quantum Elecron. QE-33 (1997) 861.

8) F. D. Patel, E. C. Honea, J. Speth, S. A. Payne, R. Hutcheson, and R. Equall: IEEE J. Quantum Elecron. QE-37 (2001) 135.

9) H. W. Bruesselbach, D. S. Sumida, R. A. Reeder, and R. W. Byren: IEEE Journal of Selected Topics in Quantum Electrons 3 (1997) 105.

10) J. Saikawa, Y. Sato, T. Taira, and A. Ikesue: Appl. Phys. Lett. 85 (2004) 1898.

11) G. Bonati: Photonics Spectra, (2003) 56.

12) D. E. McCumbe: Phys. Rev. 136 (1964) A954.

13) S. A. Payne, L. L. Chase, L. K. Smith, W. L. Kway, and W. F. Krupke: IEEE J. Quantum Elecron. QE-28 (1992) 2619.

14) J. Saikawa, S. Kurimura, I. Shoji, and T. Taira: Opt. Mat. 19 (2002) 169.

15) E. Innerhofer, T. Sdmeyer, F. Brunner, R. Hring, A. Aschwanden, R. Paschotta, C. Hnninger, M. Kumkar, and U. Keller: Opt. Lett. 28 (2003) 367

16) W. Koechner: Solid-State Laser Engineering, 5th Ed. (SpringerVerlag, 1999) p. 412.

17) D. C. Brown: IEEE J. Quantum Elecron. QE-33 (1997) 861.

18) A. Giesen, H. Hügel, A. Voss, K. Wittig, U. Brauch, and H. Opower: Appl. Phys. B, 58 (1994) 365.

19) C. Stewen, K. Contag, M. Larionov, A. Giesen, and H. H. Hügel: IEEE Journal of Selected Topics in Quantum Electrons, 6 (2000) 650.

20) D. Brown, J. Kelly, and J. Abate: IEEE J. Quantum Elecron. QE-17 (1981) 1755.

21) W. Jones, L. Goldman, J. Chernoch, and W. Martin: IEEE J. Quantum Elecron. QE-8 (1972) 535.

22) J. Eggleston, T. Kane, K. Kuhn, J. Unternahrer, and R. Byer: IEEE J. Quantum Elecron. QE-20 (1984) 289.

23) T. Rutherford, W. Tulloch, E. Gustafson, and R. Byer: IEEE J. Quantum Elecron. QE-36 (2000) 205.

24) J. Saikawa, S. Kurimura, N. Pavel, I. Shoji, and T. Taira: OSA TOPS on Advanced Solid-State Lasers 34 (2000) 106.

25) N. Pavel, J. Saikawa, and T. Taira: Jpn. J. Appl. Phys. 40 (2001) 146.

26) T. Tsunekane, T. Dascalu, and T. Taira: Extended Abstracts (The 65th Anutumn Meeting, 2004), The Japan Society of Applied Physics, 4a-P12-32 (2004) 954.

27) T. Dascalu, T. Taira, and N. Pavel: Opt. Lett. 27 (2002) 1791.

28) T. Dascalu, N. Pavel, and T. Taira: Appl. Phys. Lett. 83 (2003) 4086.

29) T. Tsunekane, T. Dascalu, and T. Taira: Extended Abstracts (The 65th Anutumn Meeting, 2004), The Japan Society of Applied Physics, 4a-P12-33 (2004) 955.

30) J. Saikawa, Y. Sato, T. Taira, and A. Ikesue, Reports on the 324th Topical Meeting of the Laser Society of Japan, RTM-04-19 (2004) 29.

J. Saikawa, Y. Sato, T. Taira, and A. Ikesue, Appl. Phys. Lett. 85 (2004) (to be published).

31) T. Taira, W. M. Tulloch, and R. L. Byer: Appl. Opt. 36 (1997) 1867.

32) T. Taira, J. Saikawa, T. Kobayshi, and R. L. Byer: IEEE J. of Select. Topics in Quantum Electron. 3 (1997) 100.

33) Y. Sato, T. Taira, N. Pavel, and V. Lupei: Appl. Phys. Lett. 82 (2003) 844.

34) Y. Sato and T. Taira: IEEE J. of Quantum Electron. 40 (2004) 270.

35) W. Krupke and L. Chase: Opt. and Quantum Electron. 22 (1990) S1.

36) S. Payne, L. DeLoach, L. Smith, W. Kway, J. Tassano, W. Krupke, B. Chai, and G. Loutts: J. Appl. Phys. 76 (1994) 497.

\section{付録 $A$ 発振効率評価に対する注意事項}

準四準位系に属するYb:YAGは, 室温においてレーザー 下準位に分布が存在するため, 発振波長の自己吸収が起 きる。しかしながら，基底状態より約 $600 \mathrm{~cm}^{-1}$ 上位にある ため, 強励起時には下準位吸収を飽和させることがで 
き, しきい值の数倍の励起領域では効率的なレーザー発 振が可能となる ${ }^{31,32)}$.

ただ，強励起が必要とされたり大きな吸収断面積を有 する材料の吸収効率評価には注意が必要で, 次式で表さ れるような吸収飽和が起きる33,34).

$$
\alpha_{\text {eff }}=\frac{\alpha_{0}}{1+\beta \frac{I_{\mathrm{p}}}{I_{\mathrm{s}}^{\mathrm{p}}}}
$$

ここで， $\alpha_{0}$ は不飽和時の吸収係数， $I_{\mathrm{p}}$ は入射光強度， $I_{\mathrm{s}}^{\mathrm{p}}$ は 飽和光強度， $\beta$ は飽和パラメータであり，準四準位レー
ザーの場合，基底準位の局所ボルツマン分布を $f_{0}$, レー ザー上準位のそれを $f_{3}$ とするなら $\beta=f_{3} / f_{0}$ となる。すなわ ち，強励起の場合，基底準位分布の枯渇が起き，吸収が 飽和する35,36)。しかし，レーザー共振器内部では，強い誘 導放出が起き，その分基底準位分布が回復するため，同 一励起強度でもレーザー発振状態，非発振状態では吸収 効率が異なる。大まかには，発振が始まるまでは吸収係 数は減少するが，しきい值以上では減少が止まると考え て良い34)。レーザー発振効率を吸収パワーに対して求め る場合や，レーザーアンプを設計する際には注意が必要 である。
イッテルビウム添加ヤグレーザー(Yb:YAG laser)

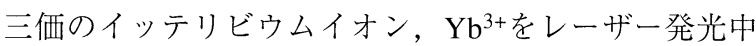
心として含む $\mathrm{YAG}$ (イットリウム・アルミニウム・ガー ネット＝ヤグ)レーザー、Yb:YAGレーザーは波長 $940 \mathrm{~nm}$ のLDにより励起され $1030 \mathrm{~nm}$ で発振する。このため励起量 子効率は91.4\%に達し，一般的な $808 \mathrm{~nm}$ 励起のNd:YAGに 比べ発熱量が $1 / 3$ 以下に抑えられ高出力動作で有利であ る。また吸収スペクトル半值幅も約 $18 \mathrm{~nm}$ と Nd:YAGに比 べ15倍近く広く，LDの波長変動に対する許容幅も広い. また, $\mathrm{Yb}^{3+}$ のオン半径が $\mathrm{Y}^{3+}$ それに近いため高濃度添 加が可能で本質的には濃度消光が起きないため, 高濃度 添加により薄いマイクロチップにおいても励起光を十分
吸収させることができる，上準位寿命は約 $1 \mathrm{~ms}$ と $\mathrm{Nd}: \mathrm{YAG}$ の4倍程度長く，励起状態吸収 (ESA) などのアップコン バージョン損失などが起こらないため高いエネルギー蓄 積効果も期待できる。加えてYb:YAGは蛍光幅が約 $8.5 \mathrm{~nm}$ とNd:YAGに比べ10倍程度広いため, 波長可変動作やフェ ムト秒の超短パルス発生も可能である。しかしながら準 四準位系レーザーであるために室温では発振光の自己吸 収があり高効率発振が阻害される場合がある。また下準 位吸収を飽和させるためには高密度励起が不可欠で， レーザー媒質へ励起，発振，冷却方法の設計には注意が 必要である。 